\title{
Pelatihan Microsoft Office dan Desain Grafis di Bina Antar Budaya Chapter Mataram
}

\author{
Budi Irmawati", Royana Afwani, Nadiyasari Agitha, \\ Sri Endang Anjarwani, M. Ali Albar \\ Program Studi Teknik Informatika, Universitas Mataram, Mataram. Indonesia
}

Kata Kunci:
Bina Antar
Budaya,
Microsoft Excel,
penjumlahan
atau
perhitungan
bersyarat,
pengurutan,
seleksi data

\begin{abstract}
Abstrak: Bina Antar Budaya adalah sebuah lembaga nirlaba non-pemerintah yang bergerak sebagai wadah bagi generasi muda untuk mengembangkan dirinya dalam berorganisasi, kepemimpinan, dan self- management. Lembaga ini berbasis relawan. Tujuan dari pendirian Lembaga ini adalah untuk membantu proses pertukaran pelajar ke luar negeri, sebagai partner dari AFS Intercultural Program (AFS). Karena sifatnya yang non-profit dan berbasis relawan, kemampuan dasar dari tiap relawan ini sangat beragam. Oleh karena itu Bina Antar Budaya mengadakan serangkaian kegiatan untuk meningkatkan kapasitas relawanrelawannya dan memberi ruang agar mereka dapat mengeluarkan potensinya. Sebagian besar kegiatan pokok lembaga ini berupa koordinasi, dokumentasi, promosi, dan pelaporan, kemampuan penguasaan aplikasi perkantoran dan manajemen website menjadi sangat penting dan wajib mereka kuasai. Dalam upaya untuk mendukung lembaga Bina Antar Budaya dan untuk meningkatkan kemampuan administrasi dan keuangan, kami memberikan penguatan dalam bentuk pelatihan penggunaan Microsoft Office dan desain grafis menggunakan Photoshop. Pelatihan ini dikemas dalam bentuk penjelasan dan praktek bersama. Materi yang diberikan berupa penggunaan fungsi-fungsi dalam Microsoft Excel seperti penjumlahan, perkalian, perhitungan bersyarat (conditional count), penjumlahan bersyarat (conditional sum), seleksi (filtering), dan pengurutan (sorting). Fungsi-fungsi tersebut sangat bermanfaat untuk melakukan seleksi terhadap pendaftar berdasarkan jenis kelamin, asal sekolah, dan usia. Fungsi tersebut juga bermanfaat untuk menghitung jumlah peserta dengan kondisi tertentu, maupun menjumlahkan data dengan kriteria tertentu. Sementara itu, untuk desain grafis, diberikan materi berupa cara menggunakan perangkat penshape dan lasso. Perangkat-perangkat tersebut digunakan untuk menggambar object dalam format vector dan mengganti latar belakan suatu citra.
\end{abstract}

Korspodensi email: budi-i@unram.ac.id

\section{PENDAHULUAN}

Bina Antar Budaya adalah sebuah lembaga nirlaba non-pemerintah yang bergerak sebagai wadah bagi generasi muda untuk mengembangkan dirinya dalam berorganisasi, kepemimpinan, dan self- management. Lembaga ini berbasis relawan. Lembaga ini berdiri secara resmi pada tanggal 2 Mei 1985 (Anonim, 2014). Pada awalnya, lembaga ini dibentuk untuk membantu proses pertukaran pelajar ke luar negeri, sebagai partner dari $A F S$ Intercultural Program (AFS). Pada awalnya, relawan-relawan Bina Antar Budaya adalah para pemuda yang telah kembali dari program pertukaran pelajar ke luar negeri.

Kegiatan-kegiatan para relawan dari lembaga ini meliputi:

1. Menyiapkan materi sosialisasi program AFS dan mensosialisasikannya ke sekolahsekolah di pulau Lombok dan Pulau Sumbawa, 
2. Melaksanakan kegiatan open house untuk memberi penjelasan mengenai program yang ditawarkan dan prosedur pendaftaran dan seleksinya.

3. Menjawab pertanyaan-pertanyaan seputar pendaftaran dan program pertukarannya,

4. Mempersiapkan proses pendaftaran calon peserta,

5. Memeriksa dan memastikan berkas para calon peserta sudah lengkap,

6. Memfasilitasi proses seleksi calon peserta yang meliputi beberapa kegiatan seperti melakukan seleksi administrasi, menghubungi para relawan yang bertugas sebagai interviewer dalam seleksi tingkat daerah, mengatur jadwal interview, mengatur proses seleksi dalam bentuk diskusi kelompok, mengatur penugasan reviewer yang hadir berdasarkan jumlah peserta, dan merekap hasil penilaian dari reviewer,

7. Mempersiapkan dan menyelenggarakan acara pembekalan untuk mempersiapkan calon peserta yang dinyatakan lulus seleksi daerah dan akan mengikuti seleksi tingkat nasional. Persiapan kegiatan ini meliputi koordinasi dengan nara sumber, mengatur jadwal pembekalan, serta melaksanakannya.

8. Melakukan kegiatan-kegiatan untuk membantu komunitas seperti membantu organisasi-organisasi dari luar NTB untuk menolong korban gempa, melakukan trauma healing pasca gempa, membuat perpustakaan mobile, dan sebagainya.

Pada perkembangannya, banyak pemerhati-pemerhati gerakan kepemudaan di Indonesia yang dilibatkan dalam proses seleksi dan pembinaan para calon peserta AFS. Keterlibatan dalam lembaga ini menjadi menarik karena para relawan merasa mendapat peningkatan kapasitas diri. Oleh sebab itu, selanjutnya para pemuda yang mendaftar program AFS banyak yang bergabung dan berproses bersama di lembaga ini, meskipun mereka tidak terpilih dalam seleksi nasional untuk mengikuti pertukaran pelajar. Dalam perkembangannya, para pemuda yang lain juga turut bergabung karena merasakan manfaat dari kegiatan ini. Apalagi, lembaga ini secara swasembada memaksimalkan potensi dari para relawannya untuk membina diri, mengadakan kegiatan-kegiatan pengembangan yang bermanfaat bagi mereka. Ada reward yang diberikan kepada relawan-relawan aktif untuk mengikuti rapat kerja di tingkat nasional, pertemuan dengan pengurus AFS di negara lain di Asia, dan mengikuti pelatihan yang diselenggarakan oleh Bina Antar Budaya Indonesia. Tentunya ada proses seleksi untuk mengikuti pelatihan ini sehingga memicu para relawan untuk meningkatkan kapasitas dirinya.

Untuk Chapter Mataram, kondisi yang sama juga berlaku. Namun, berbeda dengan chapter di kota-kota besar, para relawan ini selalu berganti karena banyak siswa yang melanjutkan studi S1 ataupun S2 nya ke kota besar. Oleh karena itu, Chapter Mataram harus lebih sering melakukan pelatihan kapasitas terhadap relawannya dan harus lebih aktif mempromosikan program yang mereka miliki baik dengan kunjungan ke sekolah-sekolah atau melalui media sosial seperti instagram dan facebook.

Karena sifatnya yang non-profit dan berbasis relawan, kemampuan dasar dari tiap relawan ini tentunya sangat beragam. Terlebih dengan keterbatasan jumlah relawan akibat roll over yang tinggi dan untuk mengurangi kesenjangan antara satu relawan dengan relawan yang lain, Bina Antar Budaya mengadakan serangkaian kegiatan untuk meningkatkan kapasitas relawan-relawannya dan memberi ruang agar mereka dapat mengeluarkan potensinya. 
Kegiatan-kegiatan yang tersebut pada halaman sebelumnya tentunya membutuhkan kemampuan manajerial, team work, komunikasi, desain, fund raising, dan dokumentasi. Dalam bidang teknologi informasi, kemampuan para relawan juga sangat bervariasi sementara penguasaan teknologi ini merupakan suatu keharusan di masa kini. Dengan bentuk kegiatan yang banyak berupa koordinasi, dokumentasi, promosi, dan pelaporan, kemampuan penguasaan aplikasi perkantoran (Weverka, 2016) dan manajemen website menjadi sangat penting dan wajib mereka kuasai. Fitur-fitur dasar Office yang sangat perlu dikuasai diantaranya adalah: mail merge, penggunaan template, pembuatan daftar isi secara otomatis, menggunakan macro untuk menghitung jumlah data dengan kriteria tertentu, membuat grafik, dan sebagainya. Sementara itu, dalam pengelolaan website diperlukan konsistensi dalam mengupdate berita, penyusunan konten yang menarik, dan memberi respon jika ada pertanyaan seputar program AFS.

Kegiatan serupa yang pernah dilakukan oleh penulis di antaranya adalah pelatihan sehari untuk instalasi Linux di SMAN 1 Mataram (Irmawati et al, 2007). Pada pelatihan ini, siswa diberikan pemahaman mengenai perangkat lunak open source dan dituntun untuk menginstal Linux Edubuntu. Penelitian lainnya adalah pembuatan perangkat lunak berbasis mobile untuk absensi siswa-siswa di SMAN 1 Gerung dan SMAN 8 Mataram. Kegiatan di SMAN 1 Gerung berupa sosialisasi menggunakan aplikasi absen berbasis mobile bagi guru dan siswa sementara kegiatan di SMAN 8 Mataram (Jatmika et al, 2017), dilakukan penyerahan aplikasi yang terinstall di komputer sekolah sebagai server dan sebuah perangkat mobile yang juga telah terinstal aplikasi tersebut (Jatmika et al, 2018). Selain itu, kegiatan serupa berupa pengenalan teknologi IoT juga telah dilaksanakan di SMA Negeri 7 Mataram (Zubaidy et al, 2019).

\section{METODE KEGIATAN}

Untuk menjamin keberhasil dalam menyelesaikan permasalahan yang dihadapi atau mengurangi beban pekerjaan karena inefisiensi, pelatihan ini melalui beberapa tahap pada Gambar 1.

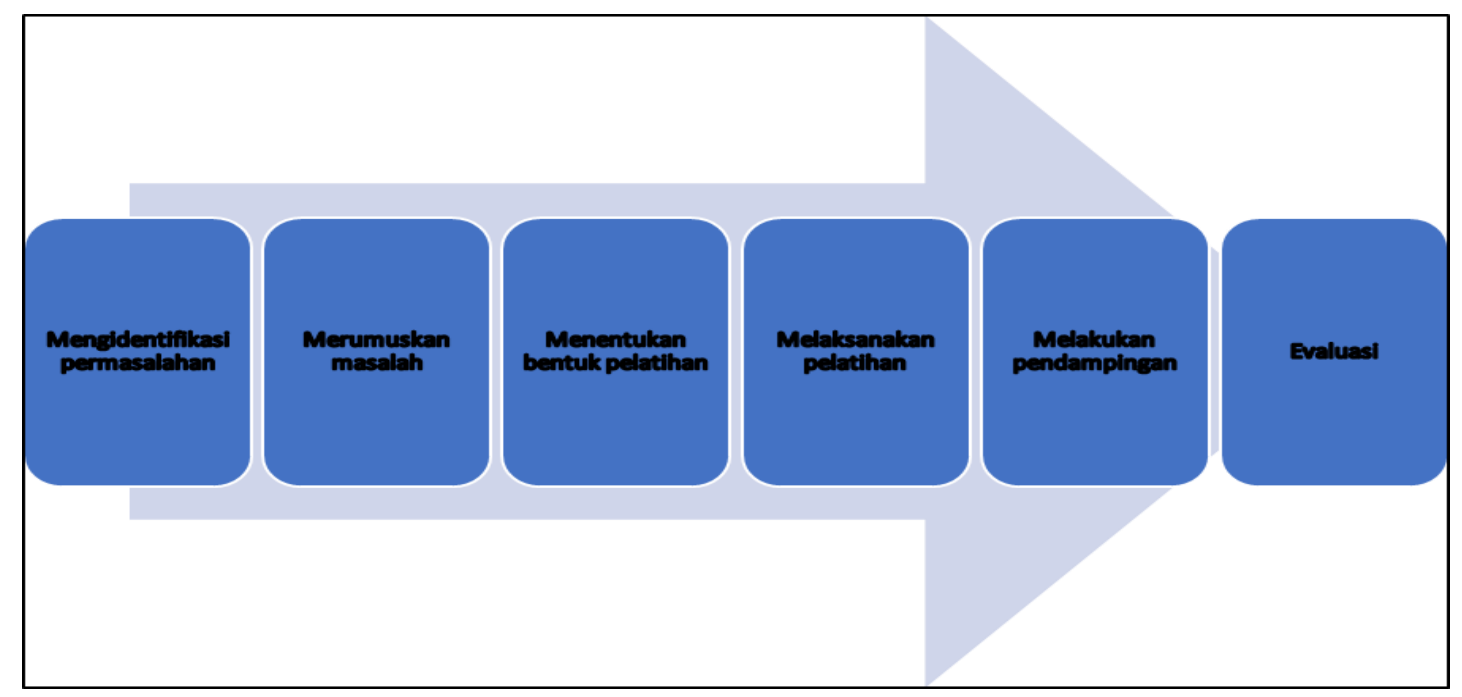

Gambar 1. Tahapan pelaksanaan pengabdian 
Gambar 1 menunjukkan bahwa pengabdian ini diawali dengan diskusi dengan mitra penerima manfaat dalam hal ini Pengelola Bina Antar Budaya Chapter Mataram. Hasil diskusi menunjukkan bahwa diperlukan penguatan pada sisi administrasi yang terdiri dari penguasaan perangkat lunak komputer pengolah kata, pengolah data, dan pengolah gambar. Langkah selanjutnya adalah menentukan skala prioritas sehingga diperoleh kesepakatan bahwa prioritas diberikan kepada desain grafis, pengolah data, dan pengolah kata. Oleh sebab itu disepakati bahwa pelatihan ini akan membahas penggunaan Microsoft Office sebagai pengolah kata dan data dan Photoshop sebagai pengolah gambar. Dalam diskusi tersebut juga ditetapkan bahwa metode yang digunakan adalah pemaparan singkat yang dilanjutkan dengan tutorial dan latihan.

\section{HASIL DAN PEMBAHASAN}

Pengabdian ini dilaksanakan selama satu hari penuh dari pukul 8:00 hingga pukul 16:00 WITA yang dibagi dalam dua sesi. Sesi pertama berupa pelatihan Photoshop, sementara sesi kedua merupakan pelatihan Microsoft Excel. Gambaran pembagian materi yang diberikan dapat dilihat pada Gambar2.

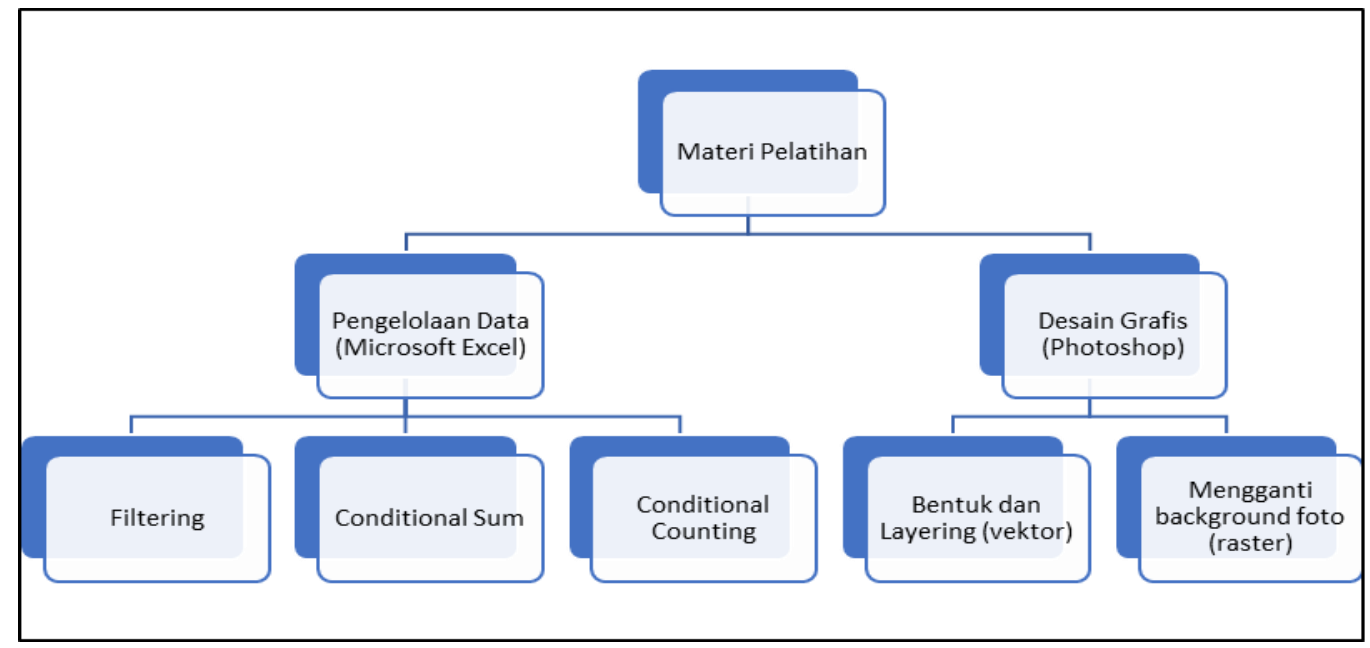

Gambar 2. Pembagian materi pelatihan

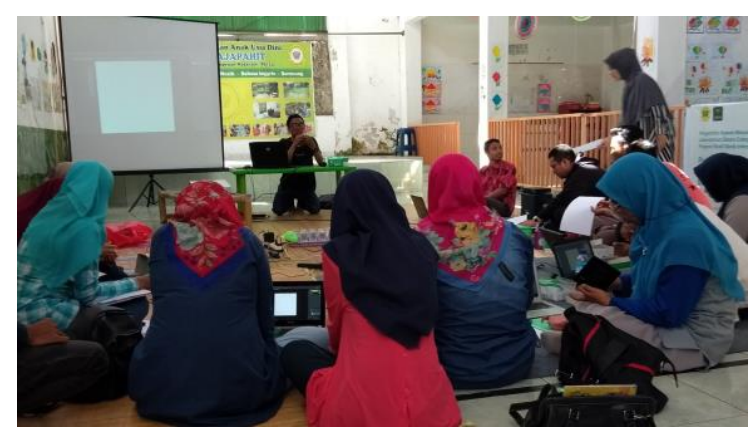

Gambar 3. Penyampaian Materi Photoshop

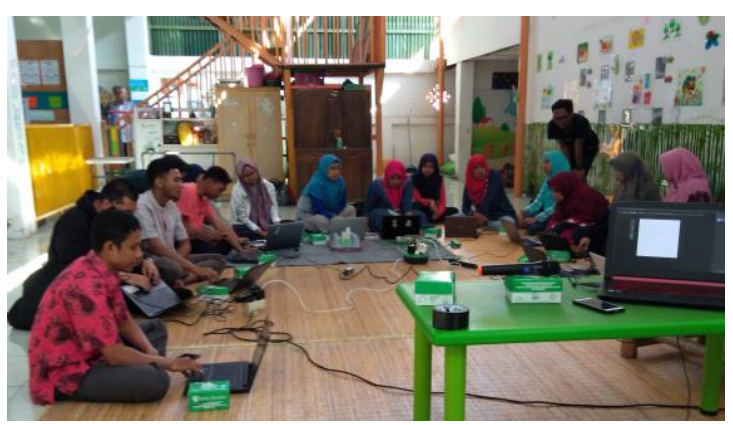

Gambar 4. Kegiatan Tutorial Photoshop

Pelatihan ini dilaksanakan di Jalan Majapahit No. 40 Ampenan yang merupakan sekretariat Bina Antar Budaya Chapter Mataram. Pada sesi pertama, diberikan penjelasan 
mengenai format data. Sesuai dengan tujuan pelatihan ini yaitu memberikan ketrampilan desain grafis, digunakan format vector sehingga desain yang dihasilkan tidak pecah ketika dilakukan perubahan ukuran. Peserta juga diberikan pengetahuan mengenai layer sehingga desain yang dihasilkan dapat saling menumpuk dan diatur transparansinya. Pelatihan Microsoft Excel dikhususkan pada penyaringan data (data filtering), penjumlahan berkondisi (conditional sum) dan counter berkondisi (conditional counting). Untuk memudahkan pemahaman, diberikan permasalahan-permasalahan sederhana seperti menghitung jumlah peserta laki-laki atau perempuan. Menampilkan hanya data peserta yang berasalah dari desa tertentu, dan semacamnya. Pelatihan Microsoft Word akhirnya ditunda mengingat kebutuhan peserta lebih banyak kepada kedua jenis kemampuan tersebut. Pelatihan ini juga belum mengajarkan bagaimana membangun grafik mengingat sudah banyak materi yang dipelajari peserta dalam satu hari. Kegiatan ini ditunjukkan pada Gambar 3 hingga 9.

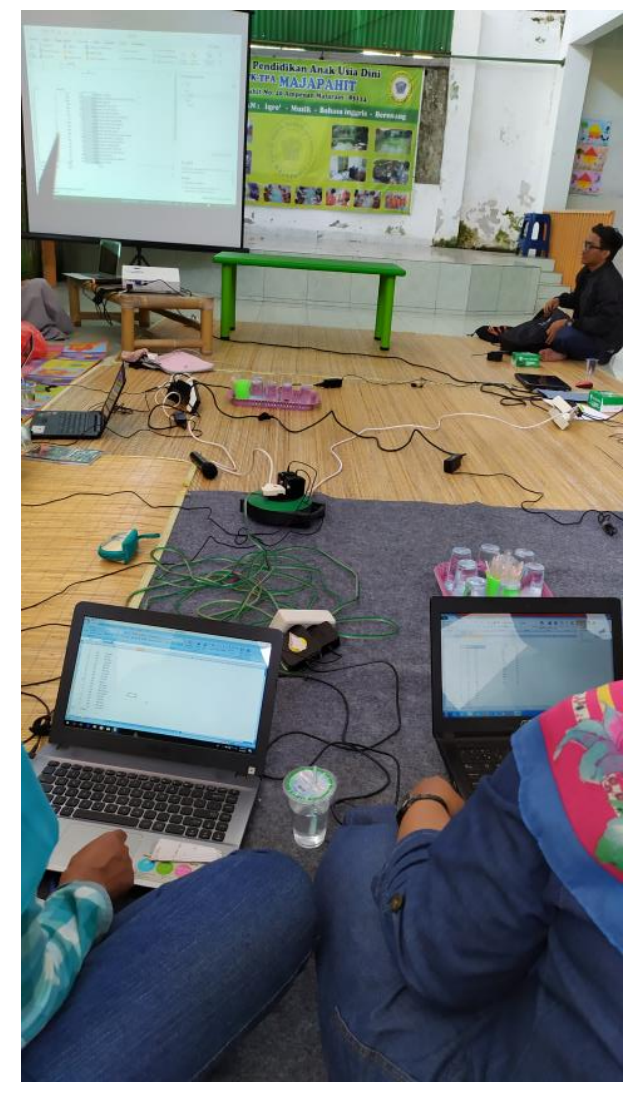

Gambar 5. Penyampaian Materi Microsoft Excel

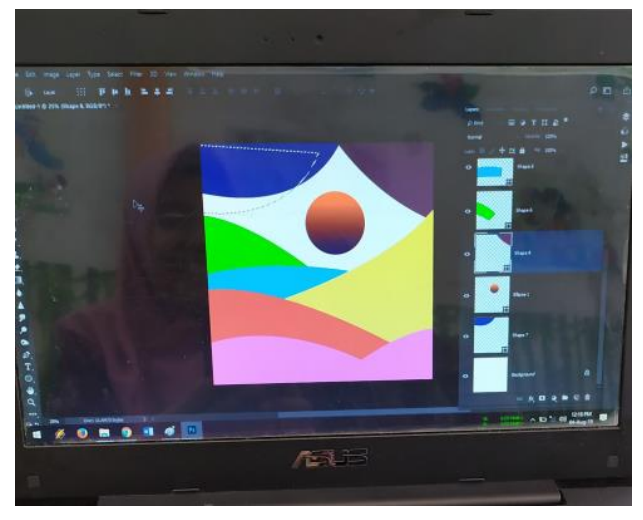

Gambar 6. Contoh tugas sebagai evaluasi

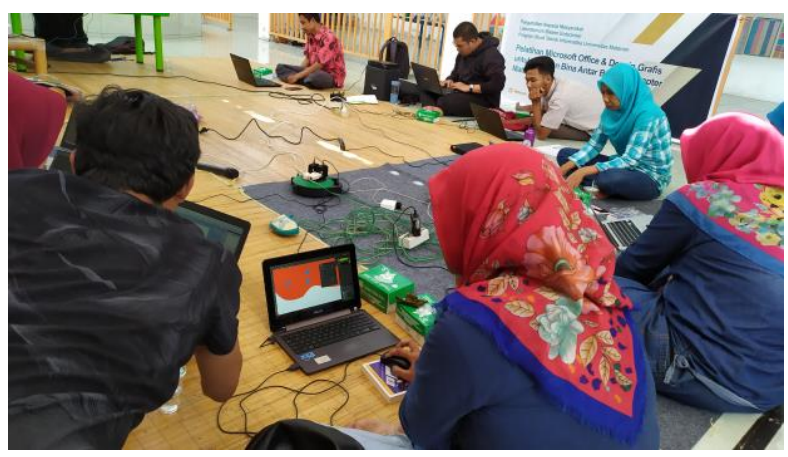

Gambar 7. Hasil desain peserta 


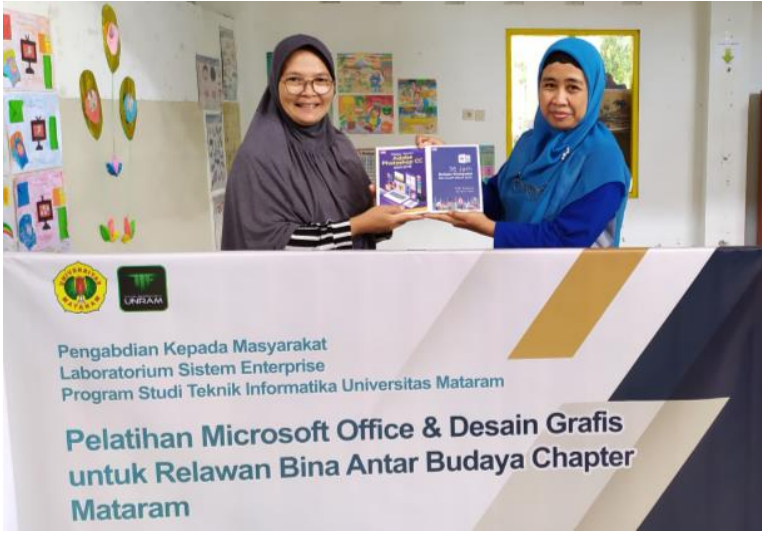

Gambar 8. Penyerahan buku Adobe Photoshop dan Microsoft Word

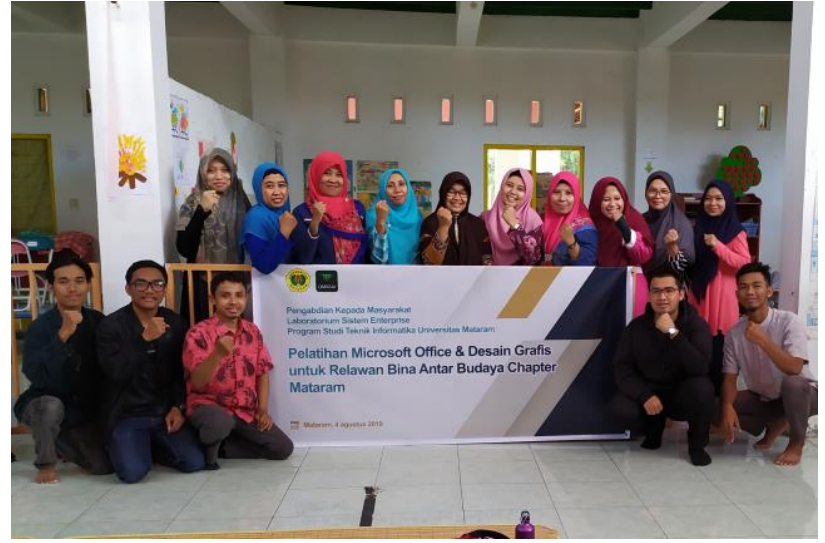

Gambar 9. Foto bersama di akhir kegiatan

Kegiatan ini juga diikuti oleh beberapa orang guru TK Majapahit yang juga bertempat di lokasi yang sama, Di luar dugaan, peserta dari guru-guru TK tersebut nampak sangat antusias karena mereka ternyata sangat membutuhkan ketrampilan tersebut. Selanjutnya untuk meningkatkan pemahaman, kami menyediakan waktu jika masih diperlukan pemdampingan bila mereka ingin bertanya atau ingin memperdalam materi yang telah diberikan. Layanan ini juga dimaksudkan untuk menjalin kesinambungan antara pelaksana dengan penerima manfaatnya.

Pada awalnya akan dilakukan pre-test dan post-test. Namun karena peserta belum pernah mendapatkan pengetahuan semacam ini, Kami menilai keberhasilannya berdasarkan peran peserta dan sejauh mana mereka dapat mengikuti materi yang diberikan. Berdasarkan pengamatan yang dilakukan, sebagian besar peserta dapat mengikuti tutorial yang diberikan.

\section{KESIMPULAN DAN SARAN}

Dari kegiatan pengabdian kepada masyarakat yang telah dilakukan, dapat disimpulkan bahwa pelaksanaan kegiatan pengabdian kepada masyarakat dapat berjalan dengan baik dengan adanya komunikasi yang aktif antara tim pengabdian kepada masyarakat dan pihak Bina Antar Budaya Chapter Mataram . Kegiatan yang dilakukan merupakan upaya untuk berbagi pengetahuan mengenai Microsoft Office dan desain grafis. Materi yang disampaikan berupa tutorial sehingga mudah diikuti dan menarik minat peserta. Untuk maksimalnya kegiatan pengabdian kepada masyarakat, maka diberikan saran-saran sebagai berikut:

1. Kegiatan pengabdian kepada masyarakat dengan tema serupa perlu dilaksanakan bagi masyarakat yang belum secara maksimal menggunakan fitur-fitur dalam aplikasi Office dan belum mengenal desain grafis, namun membutuhkan ketrampilan tersebut.

2. Unram perlu melakukan pendekatan kepada kelompok-kelompok masyarakat yang potensial membutuhkan ketrampilan serupa. 


\section{Ucapan Terima Kasih}

Penulis mengucapkan terima kasih kepada Universitas Mataram yang telah memberi dukungan financial terhadap pengabdian ini dengan DIPA BLU (PNBP), Program Studi Teknik Informatika yang telah mendukung kegiatan ini dan pihak Bina Antar Budaya Chapter Mataram yang telah memberikan kesempatan untuk melakukan kegiatan pengabdian kepada masyarakat ini, serta berbagai pihak yang tidak bisa kami sebutkan satu persatu.

\section{DAFTAR PUSTAKA}

AFS, 2019, AFS Intercultural Program, https://afsindonesia.org/, tanggal akses: 12 Februari 2019.

Bina Antar Budaya, 2014, Bina Antar Budaya, http://www.binaantarbudaya.or.id/en/pages/tentang-bina-antarbudaya.html, Tanggal akses: 12 Februari 2019.

Irmawati Budi, Natsir, Muhammad, 2006, Laporan Pengabdian kepada Masyarakat, Universitas Mataram, Mataram.

Jatmika, Andy, Irmawati, Budi, Afwani, Royana, dan Agitha, Nadiya, 2017, Pembuatan Aplikasi Absensi Online Berbasis Android sebagai Pelaporan Kehadiran Siswa untuk Mengurangi Angka Bolos Sekolah pada SMA Negeri 1 Gerung, Laporan Pengabdian kepada Masyarakat, Universitas Mataram, Mataram.

Jatmika, Andy, Irmawati, Budi, Afwani, Royana, Agitha, Nadiya, dan Wedhaswara, IGP Wirarama, 2018, Pembuatan Aplikasi Absensi Online Berbasis Android sebagai Pelaporan Kehadiran Siswa untuk Mengurangi Angka Bolos Sekolah pada SMA Negeri 8 Mataram, Laporan Pengabdian kepada Masyarakat, Universitas Mataram, Mataram.

Zubaidy, Ariyan, Wijaya, IGP Suta, Irmawati, Budi, Arimbawa, I Wayan Agus, 2019, Pengenalan Teknologi Internet of Things (IoT) bagi Siswa-siswi Sekolah Menengah Atas Negeri 7 Mataram, Jurnal Abdi Insani LPPM Unram, Nomor 1, Volume 6, Universitas Mataram, Mataram.

Weverka Peter, 2016, Office 2016 All-In-One for Dummies, O'reilly 